\title{
THE RELATION BETWEEN PSYCHOSOCIAL WORK FACTORS AND MUSCULOSKELETAL SYMPTOMS AMONG COMPUTER WORKERS
}

\section{Viktorija Prodanovska-Stojcevska ${ }^{1}$, Jovica Jovanovic $^{2}$, Tanja Jovanovska ${ }^{3}$, Domnika Rajchanovska ${ }^{4}$, Izabela Filov ${ }^{5}$, Biljana Bogdanova ${ }^{6}$}

\begin{abstract}
INTRODUCTION: Several epidemiological studies have shown that intensive computer work and other factors of work organization, involving physical and psychosocial exposure to computer work, are associated with increased risk of neck and upper extremity disorders.

OBJECTIVES:The aim of this study is to present psychosocial work factors and their relationship to musculoskeletal symptoms among computer workers.

MATERIAL AND METHODS: The Copenhagen Psychosocial Questionnaire (COPSOQ) for assessing psychosocial factors at work was used to assess 800 computer workers.

RESULTS: The results showed that most respondents often worked at a high pace; sometimes received support from superiors, and were little satisfied with work. There was a positive correlation $(r=0.3)$ between quantitative demands at work and neck symptoms.

CONCLUSION: Particular attention should be paid to psychosocial factors of the work environment, especially those with a significant high risk of workers acquiring musculoskeletal symptoms, in relation to assistance in the work environment, management, workload, and increasing autonomy at work.
\end{abstract}

UDC Classification: 614.8 DOI: http://dx.doi.org/10.12955/cbup.v4.830

Keywords: computer workers, psychosocial factors, musculoskeletal symptoms.

\section{Introduction}

Several epidemiological studies have shown that intensive computer work and other factors related to work organization, involving physical and psychosocial exposure to computer work, are associated with increased risk of neck and upper extremity disorders (Sumathy \& Raju, 2010). Studies of modern working conditions report substantial changes in work organization and content, concerning factors of downsizing, just-in-time jobs, time pressure, job demands, and decision latitude (Aronsson, 1999; Harenstam et al., 2000). Largely, these changes concern modern computerized work. The psychosocial work environment constitutes an important part of an ergonomics evaluation of a workplace. In a participatory process, it is important that workers have the opportunity to explain and describe their psychosocial work situation and identify problems affecting them. Increasing evidence suggests that exposure to adverse work organizational characteristics, such as high performance demands, coupled with low levels of job control, and low workplace social support, place individuals at increased risk of stress and illness (Karasek\&Theorell, 1990; Johnson\& Hall, 1994).

There is growing evidence within the occupational health literature that psychosocial work factors influence the development of musculoskeletal problems, including low back and upper extremity disorders (Bongers, Kremer \& Lack, 2002).

Psychosocial work factors are defined as aspects of the work environment (such as work roles, work pressure, and relationships at work) that can contribute to the experience of stress among individuals.

The National Institute for Occupational Safety and Health (NIOSH) first suggested evidence of the relationship between workplace psychosocial factors and upper extremity musculoskeletal problems

\footnotetext{
${ }^{1}$ Viktorija Prodanovska-Stojcevska, University St. Kliment Ohridski, Medical College, Bitola, Republic of Macedonia, prodanovska.stojcevska@gmail.com

2 Jovica Jovanovic, University of Niš, Medical Faculty, Niš, Republic of Serbia

${ }^{3}$ Tanja Jovanovska, University St. Kliment Ohridski, Medical College, Bitola, Republic of Macedonia

${ }^{4}$ Domnika Rajchanovska, University St. Kliment Ohridski, Medical College, Bitola, Republic of Macedonia

${ }^{5}$ Izabela Filov, University St. Kliment Ohridski, Medical College, Bitola, Republic of Macedonia

${ }^{6}$ Biljana Bogdanova, University St. Kliment Ohridski, Medical College, Bitola, Republic of Macedonia
} 
from their exploratory research (Sumathy \& Raju, 2010). Results of this research indicated that Video Display Unit (VDU) operators, who reported less autonomy and role clarity and greater work pressure and management control over their work processes, reported more musculoskeletal problems than their counterparts who did not work with VDUs.

Musculoskeletal complaints (MSCs), primarily neck, shoulder, and back pain, are the main occupational ailments. It is well known that unfavorable psychosocial work conditions add to the risk of MSCs (Aries et al., 2001; Hoogendoorn,van Poppel, Bongers, Koes, \&Bouter, 2000; Sumathy \& Raju, 2010). Self-reported demands, control, and social support have been used as indicators of psychosocial work conditions (Karasek\& Theorell, 1990). According to Baron and Kenny (Sumathy\& Raju, 2010), a mediating role of the affective stress response means that there is a relationship between psychosocial work conditions and MSCs, i.e. higher demands and lower control or social support increases the risk of MSCs. In addition, there is a relationship between psychosocial work conditions and affective stress, i.e. higher demands and lower control or social support increase the risk of negative affective stress responses. Furthermore, the relationship between psychosocial conditions and MSCs is eliminated (complete mediation), or at least significantly reduced (partial mediation), by administering effective responses.

The National Institute for Occupational Safety and Health (NIOSH, 1997) outlines five psychosocial factors that are related to back and upper extremity disorders: job satisfaction, intensified workload, monotonous work, job control, and social support.

The aim of this study is to present the psychosocial work factors and their relationship to musculoskeletal symptoms among computer workers.

\section{Material and Methods}

This research represents a cross-sectional study of computer operators. Prior to starting, researchers obtained the relevant permit from the necessary authority of the institution through which the research was conducted. The study included 800computer operators, employed across several institutions in Bitola, in the Republic of Macedonia.

The questionnaire developed to survey these employees was based on the Nordic questionnaire (Kuorinka et al., 1987) and parts of the Copenhagen Psychosocial Questionnaire (COPSOQ;Kristensen, 2002).

The standardized Nordic questionnaire applies to epidemiological studies for detecting back, neck, and shoulder pain, but does not apply to clinical diagnosis (Crawford, 2007).

The Nordic questionnaire can serve as either a questionnaire or a structured interview. The reporting of skeletal muscle discomfort is significantly higher when the questionnaire is part of a study focused on musculoskeletal problems and other work factors rather than it being part of a periodic health examination of employees (Andersson, Karlehagen \& Jonsson, 1987).

The COPSOQ is a questionnaire of varying lengths, depending on whether it is for the assessment of psychosocial factors at work, the health status of workers, or for specific individual reasons. Its main purpose is to enhance research and help implement practical interventions at a workplace (Kristensen, Hannerz, Høgh \& Borg, 2005). The concept of the questionnaire for psychosocial assessment in the workplace is valid and reliable, and is an internationally recognized tool for researching and implementing intervention at a workplace. It is also comprehensive and includes relevant measures, and according to some theories, is an important factor in the workplace. There are several versions to facilitate communication between different researchers in areas related to the assessment of health and living conditions at a workplace (Kristensen, Hannerz, Høgh \& Borg, 2005).

Data analysis was performed using the statistical program, STAT FOR WINDOWS, with results given as proportions of the arithmetic mean and standard deviation. The statistical significance level was $\mathrm{p}<0.05$. Descriptive statistics and cross correlations of the psychosocial questionnaire results were performed using STATA11 (C) Statacorp.

\section{Results}

The research was conducted with 800 respondents, whose daily work included mandatory computer operation for at least one hour. Everyone were aged $42 \pm 10.76$ years. Of these respondents, $54 \%$ were 
females and $46 \%$ were males; $28 \%$ had claimed musculoskeletal symptoms, and of these claimants, $57 \%$ were females with average age of $41.91 \pm 11.72$ years. A study into prevalence of symptoms experienced by respondents during the preceding 12 months demonstrated that most respondents had symptoms in the neck (23\%), shoulder (18\%), and, to a lesser degree, the elbow region (5\%; Prodanovska-Stojchevska, Jovanovic \& Jovanovska, 2015).

Table 1: Descriptive statistics of the psychosocial questionnaire results from responses of 800 computer workers

\begin{tabular}{|c|c|c|c|c|c|}
\hline Variable & Observation & Arithmeticmean & $\begin{array}{l}\text { Standard } \\
\text { deviation }\end{array}$ & Min & Max \\
\hline \multicolumn{6}{|c|}{ 1. Do you get behind with your work? } \\
\hline Always & 800 & 0.010 & 0.111 & 0 & 1 \\
\hline Often & 800 & 0.028 & 0.164 & 0 & 1 \\
\hline Sometimes & 800 & 0.119 & 0.324 & 0 & 1 \\
\hline Seldom & 800 & 0.410 & 0.490 & 0 & 1 \\
\hline Never & 800 & 0.430 & 0.496 & 0 & 1 \\
\hline \multicolumn{6}{|c|}{ 2. Do you work at a high pace throughout the day? } \\
\hline Always & 800 & 0.200 & 0.390 & 0 & 1 \\
\hline Often & 800 & 0.380 & 0.480 & 0 & 1 \\
\hline Sometimes & 800 & 0.340 & 0.470 & 0 & 1 \\
\hline Seldom & 800 & 0.060 & 0.240 & 0 & 1 \\
\hline Never & 800 & 0.006 & 0.078 & 0 & 1 \\
\hline \multicolumn{6}{|c|}{ 3. Does your work put you in emotionally disturbing situations? } \\
\hline Always & 800 & 0.050 & 0.220 & 0 & 1 \\
\hline Often & 800 & 0.160 & 0.370 & 0 & 1 \\
\hline Sometimes & 800 & 0.390 & 0.488 & 0 & 1 \\
\hline Seldom & 800 & 0.270 & 0.440 & 0 & 1 \\
\hline Never & 800 & 0.118 & 0.320 & 0 & 1 \\
\hline \multicolumn{6}{|c|}{ 4. Can you influence the amount of work assigned to you? } \\
\hline Always & 800 & 0.113 & 0.318 & 0 & 1 \\
\hline Often & 800 & 0.188 & 0.390 & 0 & 1 \\
\hline Sometimes & 800 & 0.280 & 0.449 & 0 & 1 \\
\hline Seldom & 800 & 0.256 & 0.430 & 0 & 1 \\
\hline Never & 800 & 0.155 & 0.362 & 0 & 1 \\
\hline \multicolumn{6}{|c|}{ 5. Do you have the possibility of learning new things through your work? } \\
\hline Always & 800 & 0.230 & 0.420 & 0 & 1 \\
\hline Often & 800 & 0.308 & 0.460 & 0 & 1 \\
\hline Sometimes & 800 & 0.345 & 0.475 & 0 & 1 \\
\hline Seldom & 800 & 0.075 & 0.260 & 0 & 1 \\
\hline Never & 800 & 0.038 & 0.193 & 0 & 1 \\
\hline \multicolumn{6}{|c|}{ 6. Does your work require you to take the initiative? } \\
\hline Always & 800 & 0.210 & 0.410 & 0 & 1 \\
\hline Often & 800 & 0.285 & 0.451 & 0 & 1 \\
\hline Sometimes & 800 & 0.387 & 0.487 & 0 & 1 \\
\hline Seldom & 800 & 0.069 & 0.253 & 0 & 1 \\
\hline Never & 800 & 0.043 & 0.204 & 0 & 1 \\
\hline \multicolumn{6}{|c|}{ 7. Do you feel that the work you do is important? } \\
\hline Always & 800 & 0.043 & 0.204 & 0 & 1 \\
\hline Often & 800 & 0.430 & 0.490 & 0 & 1 \\
\hline Sometimes & 800 & 0.380 & 0.480 & 0 & 1 \\
\hline Seldom & 800 & 0.150 & 0.365 & 0 & 1 \\
\hline Never & 800 & 0.0130 & 0.116 & 0 & 1 \\
\hline \multicolumn{6}{|c|}{ 8. Does your work have clear objectives? } \\
\hline Always & 800 & 0.007 & 0.086 & 0 & 1 \\
\hline Often & 800 & 0.389 & 0.488 & 0 & 1 \\
\hline Sometimes & 800 & 0.430 & 0.495 & 0 & 1 \\
\hline Seldom & 800 & 0.164 & 0.370 & 0 & 1 \\
\hline Never & 800 & 0.011 & 0.105 & 0 & 1 \\
\hline \multicolumn{6}{|c|}{ 9. How often do you get help and support from your nearest superior? } \\
\hline Always & 800 & 0.006 & 0.0789 & 0 & 1 \\
\hline Often & 800 & 0.222 & 0.416 & 0 & 1 \\
\hline
\end{tabular}




\begin{tabular}{|c|c|c|c|c|c|}
\hline Sometimes & 800 & 0.315 & 0.465 & 0 & 1 \\
\hline Seldom & 800 & 0.265 & 0.442 & 0 & 1 \\
\hline Never & 800 & 0.136 & 0.343 & 0 & 1 \\
\hline \multicolumn{6}{|c|}{$\begin{array}{l}\text { 10. Regarding your work in general, how pleased are you with your job as a whole, everything taken int } \\
\text { consideration? }\end{array}$} \\
\hline Very satisfied & 800 & 0.057 & 0.233 & 0 & 1 \\
\hline Satisfied & 800 & 0.256 & 0.437 & 0 & 1 \\
\hline Little & 800 & 0.654 & 0.476 & 0 & 1 \\
\hline Unsatisfied & 800 & 0.070 & 0.255 & 0 & 1 \\
\hline Very unsatisfied & 800 & 0.019 & 0.136 & 0 & 1 \\
\hline \multicolumn{6}{|c|}{$\begin{array}{l}\text { 11. Do you feel that your work drains so much of your energy that it has a negative effect on your private } \\
\text { life? }\end{array}$} \\
\hline In very large extent & 800 & 0.157 & 0.364 & 0 & 1 \\
\hline Large extent & 800 & 0.376 & 0.485 & 0 & 1 \\
\hline Somewhat & 800 & 0.250 & 0.433 & 0 & 1 \\
\hline To a small extent & 800 & 0.212 & 0.409 & 0 & 1 \\
\hline To a very small extent & 800 & 0.171 & 0.377 & 0 & 1 \\
\hline \multicolumn{6}{|c|}{ 12. Are conflicts resolved in a fair way? } \\
\hline In very large extent & 800 & 0.352 & 0.478 & 0 & 1 \\
\hline Large extent & 800 & 0.377 & 0.485 & 0 & 1 \\
\hline Somewhat & 800 & 0.062 & 0.242 & 0 & 1 \\
\hline To a small extent & 800 & 0.035 & 0.184 & 0 & 1 \\
\hline To a very small extent & 800 & 0.135 & 0.342 & 0 & 1 \\
\hline \multicolumn{6}{|c|}{ 13. Is the work distributed fairly? } \\
\hline In very large extent & 800 & 0.302 & 0.460 & 0 & 1 \\
\hline Large extent & 800 & 0.409 & 0.492 & 0 & 1 \\
\hline Somewhat & 800 & 0.084 & 0.277 & 0 & 1 \\
\hline To a small extent & 800 & 0.066 & 0.254 & 0 & 1 \\
\hline To a very small extent & 800 & 0.165 & 0.371 & 0 & 1 \\
\hline \multicolumn{6}{|c|}{ 14. In general, would you say your health is } \\
\hline Excellent & 800 & 0.300 & 0.458 & 0 & 1 \\
\hline Very good & 800 & 0.436 & 0.496 & 0 & 1 \\
\hline Good & 800 & 0.080 & 0.271 & 0 & 1 \\
\hline Fair & 800 & 0.016 & 0.126 & 0 & 1 \\
\hline Poor & 800 & 0.015 & 0.122 & 0 & 1 \\
\hline \multicolumn{6}{|c|}{ 15. How often have you been emotionally exhausted? } \\
\hline All the time & 800 & 0.155 & 0.362 & 0 & 1 \\
\hline A large part of the time & 800 & 0.417 & 0.493 & 0 & 1 \\
\hline Part of the time & 800 & 0.327 & 0.470 & 0 & 1 \\
\hline A small part of the time & 800 & 0.082 & 0.275 & 0 & 1 \\
\hline Not at all & 800 & 0.030 & 0.171 & 0 & 1 \\
\hline \multicolumn{6}{|c|}{ 16. How often have you been stressed? } \\
\hline All the time & 800 & 0.149 & 0.356 & 0 & 1 \\
\hline A large part of the time & 800 & 0.377 & 0.485 & 0 & 1 \\
\hline Part of the time & 800 & 0.35 & 0.477 & 0 & 1 \\
\hline A small part of the time & 800 & 0.094 & 0.292 & 0 & 1 \\
\hline Not at all & 800 & 0.006 & 0.079 & 0 & 1 \\
\hline \multicolumn{6}{|c|}{ 17. How often have you feel sad? } \\
\hline All the time & 800 & 0.056 & 0.231 & 0 & 1 \\
\hline A large part of the time & 800 & 0.266 & 0.442 & 0 & 1 \\
\hline Part of the time & 800 & 0.427 & 0.495 & 0 & 1 \\
\hline Not at all & 800 & 0.244 & 0.430 & 0 & 1 \\
\hline \multicolumn{6}{|c|}{ 18. How often have you are in a bad mood? } \\
\hline All the time & 800 & 0.007 & 0.086 & 0 & 1 \\
\hline A large part of the day & 800 & 0.040 & 0.196 & 0 & 1 \\
\hline Part of the day & 800 & 0.315 & 0.465 & 0 & 1 \\
\hline Not at all & 800 & 0.507 & 0.500 & 0 & 1 \\
\hline
\end{tabular}

In addition, issues relating to the measurable demands in the workplace positively correlated to appearance of symptoms in the wrist and hand $(\mathrm{r}<0.3)$. 
Table 2. Cronbach's alpha inter-correlation scale

\begin{tabular}{|l|l|}
\hline The average variance between the questions & 0.0063 \\
\hline Number of ans wers & 88 \\
\hline Cronbach's alpha coefficient & $\mathbf{0 . 8 0 8 1}$ \\
\hline
\end{tabular}

Source: Cortina (1993)

\section{Discussion}

The results of the Nordic questionnaire from previous studies showed that the most prevalent symptoms in computer workers are in the neck (48\%), upper back (48\%), and the lower part of the back (42\%) areas (Prodanovska-Stojchevska, Jovanovic, Jovanovska \& Isjanovska, 2012). These results relate to potential risk in the relationship between posture and appearance of musculoskeletal symptoms in computer operators, and show that the workers most affected are those who maintain the same posture and perform repetitive tasks while working throughout the day, with their head bent over in front of the computer (Prodanovska-Stojchevska, Jovanovic \& Jovanovska, 2015).

The analyses of the psychosocial questionnaire results involving 800 computer operators showed that the largest number of respondents never delayed their work, often worked at a high pace, and felt emotional stressed. They were sometimes affected by the amount of work that had to be performed and sometimes had the opportunity to influence new businesses. They felt they could sometimes show initiative; often believed that their work was important; and that their jobs had clearly defined goals. Further, they sometimes received support and help from their manager, were only slightly satisfied with their work, and considered their work drained them of energy and negatively affected their personal life to a large extent. They largely resolved conflicts in a fair manner, and considered their job as properly distributed and their health as very good. For most of the working time, they felt emotionally exhausted, and usually exerted a lot of effort, felt sad sometimes, but were never in a bad mood.

Psychosocial factors in the workplace are one of the most important topics in the modern world (European Commission Guidance on work-related stress, 2000; Cox, Griffiths \& Rial-González, 2000; Kompier, 2002; Paoli \& Merllié, 2001; Kompier, 2003). A large number of reports and papers from the European Union (EU), regarding the exposure to psychosocial stress at work and significant consequences of stress in the workplace, indicate a strong interest by the whole of society in this problem. Among the consequences of stress that need emphasis, are musculoskeletal disorders, cardiovascular disease, mental illness, post-traumatic stress disorder, burnout, decreased quality of life, absenteeism, decreased motivation for work, and reduced productivity. The EU Member States refer to psychosocial factors as having a significant role in the work environment, and European institutes for the work environment estimate that psychosocial factors will be the most important field of research in the near future (European Agency for Safety and Health at Work, 2000; Marklund, 2000). The National Institute for Occupational Safety and Health (1997) highlights five psychosocial factors associated with pain in the spine and upper limb disorders: job satisfaction, workload, monotonous jobs, job control, and social support.

The cross-correlation analysis of psychosocial factors and symptoms among computer operators in this present study indicated a positive correlation between measurable indicators of employment (the rate at which work is being performed) and the onset of symptoms in the neck area, wrist, and hand. A similar correlation was found between emotional disturbance and intense effort at work with the appearance of symptoms in the shoulder regions of the computer operators surveyed.

The relationship between psychosocial work factors and the occurrence of musculoskeletal symptoms in the upper extremities has been investigated by NIOSH (1997). Their results showed that computer operators, who are less autonomous and have greater work demands and higher external control over their work, suffer from musculoskeletal disorders more frequently than other workers (Smith, Cohen, Stammerjohn, 1981).

Psychosocial factors have been analyzed in previous studies (Shahla, Bart, Amar \& Rob A. de Bie, 2009). Data show that increased demands of work, reduced opportunity to make decisions, work pressure, increased exertion, job dissatisfaction, and lack of social support from colleagues and 
superiors are important risk factors for the occurrence of upper limb disorders (Eltayeb, Staal, Hassan, $\&$ de Bie, 2009).

A study, conducted in Norway, examined job requirements, control in the execution of tasks, social support, and effort at work. The results showed a correlation between the execution of difficult tasks in the workplace and the occurrence of symptoms in the neck and shoulders. These results are consistent with other prospective studies in which the jobs requirements were shown as risk factors in the occurrence of pain in the neck area (Eltayeb et al., 2009; Ariens, Bongers, Hoogendoorn, van der Wal\& van Mechelen, 2002).

Lena Karlqvist and associates (2002) have demonstrated in their study that there is a significant association between psychosocial factors and work exertion in terms of musculoskeletal symptoms in the neck and shoulders. Work effort correlated moderately with the appearance of symptoms in the neck and shoulder in several other studies (Bernard, 1997; Hagberg et al.,1995; Theorell, 1996).

There is a large amount of evidence in literature indicating psychosocial factors in the workplace have a great role in the appearance of musculoskeletal symptoms and disorders. The results provided in this research are in accordance with those cited in other written material on this topic.

\section{Conclusion}

The psychosocial working environment denotes a significant part of the ergonomic evaluation of the working place. It is important to mention that computer workers should have the opportunity to explain and describe the psychosocial climate at their workplace, and thus identify the problems that appear throughout their daily working time. The number of evidenced claims for exposure to unsatisfactory work conditions, like poor workload organization, increased number of demands, and a low level of work control and social support in the workplace, that increase the risk of stress and diseases in the exposed workers, is significantly increasing (Karasek and Theorell, 1990).

\section{References}

Andersson, K., Karlehagen, S., \& Jonsson, B. (1987). The importance of variations in questionnaire administration. Appl Ergon, 18:229-232.

Ariens, G. A., Bongers, P. M., Hoogendoorn, W. E., van der Wal, G., \& van Mechelen, W. (2002). High physical and psychosocial load at work and sickness absence due to neck pain. Scand J Work Environ Health, 28:222-31.

Aries, G. A., Bongers, P. M., Miedema, M. C., Hoogendoorn, W. E., van derWal, G., Bouter, L. M., \& van Mechelen, W. (2001). Are neck flexion, neck rotation, and sitting at work risk factors for neck pain? Results of a prospective cohort study. Occup Environ Med, 58(3):200-207.

Aronsson, G. (1999). Contingent workers and health and safety. Work Employment and Society 13, 439-459.

Bernard, B.P. (Ed.) (1997). Musculoskeletal Disorders and Workplace Factors. A Critical Review of Epidemiological Evidence for Work-Related Musculoskeletal Disorders of the Neck, Upper Extremity, and Low Back. National Institute for Occupational Safety and Health, Cincinatti.

Bongers, P., Kremer, A., \& Lack, J. (2002). Are psychosocial factors, risk factors for symptoms and signs of the shoulder, elbow, or hand/wrist?: a review of the epidemiological literature. American Journal of Industrial Medicine 41, 315-342.

Cortina, J. M. (1993). "What is coefficient alpha? An examination of theory and applications". Journal of Applied Psychology 78: 98-104.

Cox, T., Griffiths, A., \& Rial-González, E. (2000). Research on work related stress. Luxembourg: Office for Official Publications of the European Communities.

Crawford, O. J. (2007). The Nordic Musculoskeletal Questionnaire Occup Med (Lond), 57 (4): 300301.DOI: $10.1093 /$ occmed/kqm036

European Agency for Safety and Health at Work (2000). Future occupational safety and health research needs and priorities in the member states of the European Union. Luxembourg: Office for Official Publications of the European Communities.

European Commission (2000). Guidance on work-related stress: spice of life or kiss of death? Luxembourg: Office for Official Publications of the European Communities.

Hagberg, M., Silverstein, B., Wells, R., Smith, M. J., Hendrick, H.W., Carayon, P., \& Pérusse, M. (1995). In: Kuorinka, I., Forcier, L. (Eds.), Work Related Musculoskeletal Disorders (WMSDs): A Reference Bookfor Prevention. Taylor \& Francis, London.

Harenstam, A., Westberg, H., Karlqvist, L., Nise, G., Leijon, O., Rydbeck, A., Waldenstrom, K., \& Wiklund, P. (2000). How can gender differences in working and living conditions be comprehended? ArbeteochHalsa 15.

Hoogendoorn, W. E., van Poppel, M. N., Bongers, P. M., Koes, B. W., \& Bouter, L. M. (2000). Systematic review of psychosocial factors at work and private life as risk factors for back pain, Spine (Phila Pa). 15; 25(16):2114-25. 
Johnson, J. V. \& Hall, E. M. (1994). `Social support in the work environment and cardiovascular disease'. In: Shumaker, S

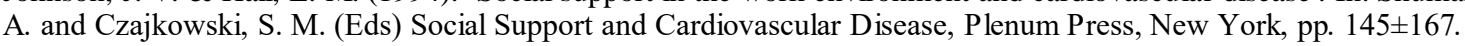

Karasek, R., \& Theorell, T. (1990). Healthy Work, Stress, Productivity and the Reconstruction of Working Life. Basic Books Inc. Publishers, New York.

Kompier, M. (2002). The psychosocial work environment and health - what do we know and where should we go? [editorial]. Scand J Work Environ Health; 28(1):1-4.

Kompier, M. (2003). Job design and well-being. In: Schabracq MJ, Winnubst JAM, Cooper CL, editors. The handbook of work and health psychology. Chichester (UK): John Wiley \& Sons; p 429-54.

Kristensen, T. S., Hannerz, H., Høgh, A., \& Borg, V. (2005). The Copenhagen Psychosocial Questionnaire - a tool for the assessment and improvement of the psychosocial work environment. Scand J Work Environ Health; 31(6):438-449.

Kristensen, T. S. (2002). A new tool for assessing psychosocial factors at work: The Copenhagen Psychosocial Questionnaire. TUTB Newsletter, 19-20:45-47.

Kuorinka, I., Jonsson, B., Kilbom, A., Vinterberg, H., Biering-Sorensen, F., Andersson, G., \& Jorgensen, K. (1987). Standardised Nordic questionnaires for the analysis of musculoskeletal symptoms. Appl Ergon, 18(3):233-237.

Karlqvist, L., Wigaeus Tornqvist, E., Hagberg, M., Hagman, M. \& Toomingas, A. (2002). Self-reported working conditions of VDU operators and associations with musculoskeletal symptoms: a cross sectional study focusing on gender differences. International Journal of Industrial Ergonomics, 30, 277-294.

Marklund, S. (2000). Questionnaire survey on research priorities. In: Westerholm P, Marklund S, editors. Strategies for occupational health research in a changing Europe. Stockholm: National Institute for Working Life; p 31-3. ArbeteochHälsa, vol 12.

National Institute for Occupational Safety and Health (NIOSH) (1997). Musculoskeletal Disorders and Workplace Factors, Publication No. 97-141.

Paoli, P., \& Merllié, D. (2001). Third European survey on working conditions 2000. Dublin: European Foundation for the Improvement of Living and Working Conditions.

Prodanovska-Stojchevska, V., Jovanovic, J., Jovanovska, T., \& Isjanovska, R. (2012). Evaluation of computer workstation ergonomics and prevalence of the musculoskeletal symptoms-A cross sectional study of Macedonian office workers. Healthmed Journal 6(10):3532-3537.

Prodanovska-Stojchevska, V., Jovanovic, J., \& Jovanovska, T. (2015). Body posture in relation with musculoskeletal symptoms amongst computer operators. British Journal of Medicine and Medical Research 7(3): 2013-210. ISSN: 22310614.

Eltayeb, S., Staal, B., Hassan, A., \& de Bie, R. A. (2009). Work Related Risk Factors for Neck, Shoulder and Arms Complaints: A Cohort Study Among Dutch Computer Office Workers J Occup Rehabil; 19:315-322.

Smith, M. J., Cohen, B. G., \& Stammerjohn, L. W. Jr. (1981). An investigation of health complaints and job stress in video display operations. Human Factors; 23:387-400.

Sumathy, M., \& Raju, R. (2010). The Influence of Psychosocial Factors on the Occurrence of Musculoskeletal Disorders Regarding VDT Users. European Journal of Scientific Research, Vol.43 No.2, pp.290-296.

Theorell, T. (1996). Possible mechanisms behind the relationship between the demand-control-support model and disorders of the locomotor system. In: Moon, S.D., Sauter, S.L. (Eds.), Beyond Biomechanics. Psychosocial Aspects of Musculoskeletal Disorders in Office Work. Taylor \& Francis, London, pp. 65-74. 